\title{
On the origin and evolution of Antarctic Peracarida (Crustacea, Malacostraca)*
}

\author{
ANGELIKA BRANDT \\ Zoological Institute and Zoological Museum, Martin-Luther-King-Platz 3, D-20146 Hamburg, Germany \\ Dedicated to Jürgen Sieg, who silently died in 1996. He inspired this research with his important account of the \\ zoogeography of the Antarctic Tanaidacea.
}

\begin{abstract}
SUMMARY: The early separation of Gondwana and the subsequent isolation of Antarctica caused a long evolutionary history of its fauna. Both, long environmental stability over millions of years and habitat heterogeneity, due to an abundance of sessile suspension feeders on the continental shelf, favoured evolutionary processes of "preadapted" taxa, like for example the Peracarida. This taxon performs brood protection and this might be one of the most important reasons why it is very successful (i.e. abundant and diverse) in most terrestrial and aquatic environments, with some species even occupying deserts. The extinction of many decapod crustaceans in the Cenozoic might have allowed the Peracarida to find and use free ecological niches. Therefore the palaeogeographic, palaeoclimatologic, and palaeo-hydrographic changes since the Palaeocene (at least since about $60 \mathrm{Ma}$ ago) and the evolutionary success of some peracarid taxa (e.g. Amphipoda, Isopoda) led to the evolution of many endemic species in the Antarctic. Based on a phylogenetic analysis of the Antarctic Tanaidacea, Sieg (1988) demonstrated that the tanaid fauna of the Antarctic is mainly represented by phylogenetically younger taxa, and data from other crustacean taxa led Sieg (1988) to conclude that the recent Antarctic crustacean fauna must be comparatively young. His arguments are scrutinized on the basis of more recent data on the phylogeny and biodiversity of crustacean taxa, namely the Ostracoda, Decapoda, Mysidacea, Cumacea, Amphipoda, and Isopoda. This analysis demonstrates that the origin of the Antarctic fauna probably has different roots: an adaptive radiation of descendants from old Gondwanian ancestors was hypothesized for the isopod families Serolidae and Arcturidae, an evolution and radiation of phylogenetically old taxa in Antarctica could also be shown for the Ostracoda and the amphipod family Iphimediidae. A recolonization via the Scotia Arc appears possible for some species, though it is not very likely (some Isopoda, like the Sphaeromatidea, are widely distributed in the Subantarctic, but rare in the high Antarctic). However, it could also be that the species of this family and others were not able to survive when the ice reached the sublittoral shelf in the high Antarc-
\end{abstract} tic during glacial periods.

Key words: Crustacea, Peracarida, Antarctic, Magellan region, evolution, origin, biogeography.

RESUMEN: Sobre el origen y la eVolución de Peracarida (CRustacea, malacostraca) De la Antártida. - La separación de Gondwana y el subsecuente aislamiento de la Antártida dió lugar a la larga historia evolutiva de su fauna. La larga estabilidad ambiental a lo largo de millones de años y la heterogeneidad de hábitats, debida a una abundancia de suspensívoros bentónicos sésiles en la plataforma continental, favorecieron los procesos evolutivos de los taxones "preadaptados", como por ejemplo los Peracarida. Este taxón, que desarrolló mecanismos de protección de las crías, es muy exitoso (abundante y con una elevada diversidad) en la mayoría de los ambientes acuáticos y terrestres, inclusive en desiertos. La extinción de muchos crustáceos decápodos durante el Cenozoico pudo haber permitido a los Peracarida encontrar y explotar nichos ecológicos que quedaron libres. Por tanto los cambios paleogeográficos, paleoclimatológicos y paleohidrográficos ocurridos desde el Paleoceno (como mínimo desde hace 60 millones de años) y los procesos evolutivos de algunos taxones de Peracarida (por ejemplo Amphipoda e Isopoda) condujeron hacia la evolución de bastantes especies endémicas en la Antártida. Basándose en el análisis filogenético de los Tanaidacea antárticos, Sieg (1988) demostró que la fauna de Tanaidacea de la Antártida está representada principalmente por taxones filogenéticamente jóvenes; datos de otros taxones de crustáceos llevaron a Sieg (1988) a la conclusión de que la fauna reciente de crustáceos antárticos debe ser comparativamente joven. Estos argumentos han sido reexaminados basándose en los datos más recientes sobre la filogenia y biodi-

*Accepted August 31, 1998. 
versidad de los taxones de los siguientes crustáceos: Ostracoda, Decapoda, Mysidacea, Cumacea, Amphipoda e Isopoda. Este análisis demuestra que el origen de la fauna antártica probablemente tiene diferentes raíces: se ha planteado la hipótesis de una radiación adaptativa de los descendientes de antiguos ancestros de Gondwana para las siguientes familias de Isopoda: Serolidae y Arcturidae; los Ostracoda y la familia de Amphipoda Iphimediidae, podrían mostrar también una evolución y radiación de taxones filogenéticamente antiguos en la Antártida. La recolonización a través del Arco de Escocia parece posible para algunas especies, aunque no es muy probable (algunos, como los Sphaeromatidea están ampliamente distribuidos en las zonas subantárticas, pero raramente en la alta Antártida). Por otro lado, también sería posible que las especies de esta familia y de otras, no hayan sido capaces de sobrevivir en las situaciones en que el hielo alcanzaba la plataforma sublitoral en la alta Antártida durante los períodos glaciales.

Palabras claves: Crustacea, Peracarida, Antártida, región de Magallanes, evolución, orígen, biogeografía.

\section{INTRODUCTION}

The proper basis for studies of evolutionary biology or zoogeographic origin of taxa is phylogenetic analysis. The fossil record greatly facilitates the recognition of plesiomorphic (ancient) or apomorphic (derived) character states, but unfortunately fossils are only available for some taxa, and fossil Peracarida (Crustacea, Malacostraca) from the Southern Ocean are too scarce to be used for phylogenetic analyses of the recent Antarctic species. Therefore at present evolution and origin of Antarctic Peracarida are still unclear for many taxa, as only few analyses of phylogenetic biogeography have been completed (e.g. Watling and Thurston, 1989; Brandt, 1991; Wägele, 1994). However, the necessary initial faunistic inventory of many peracarid taxa has been completed recently (e. g. Sieg, 1983, 1984, 1986, 1988; Brandt, 1991, 1992; Mühlenhardt-Siegel, 1999; Brandt et

TABLE 1. - The supraorder Peracarida consists of seven orders. Five of these occur in the Antarctic. The number in brackets represent estimated species numbers (world wide) for each peracarid taxon.

\begin{tabular}{lcl}
\hline Amphipoda $^{1}$ & 6000 \\
Cumacea $^{1}$ & 1253 \\
Isopoda $^{1}$ & 10000 \\
Mysidacea $^{1}$ & 780 \\
Tanaidacea $^{1}$ & 600 \\
Mictacea $^{2}$ & 3 & \\
Spelaeogriphacea $^{3}$ & 2 & \\
\hline Allocats
\end{tabular}

${ }^{1}$ All oceans, polar to deep sea

${ }^{2}$ Caves, Bermuda, Brasil

${ }^{3}$ Caves, South Africa al., 1998; Watling and Thurston, 1989; De Broyer and Jazdzewski, 1993, 1996), and this will form the basis of this review.

The supraorder Peracarida consists of seven orders (Table 1), and five of these are known to occur in the Antarctic: Amphipoda, Cumacea, Isopoda, Mysidacea and Tanaidacea (Table 1; the numbers represent estimates of the world wide species richness for each taxon). The value for the Amphipoda is probably underestimated, as about 6000 species were described until 1986 (De Broyer and Jazdzewski, 1993). According to De Broyer and Jazdzewski (1996) 110 new species of Amphipoda are described on average every year, yielding an estimated number of more than 7000 species worldwide (this estimate, however, is not published yet). The species richness for Isopoda is the highest, probably due to the tremendous biodiversity of terrestrial tropical oniscids.

\section{HISTORICAL BACKGROUND FOR THE EVOLUTION OF THE PERACARIDA (HISTORICAL GEOGRAPHY)}

The major steps of the breakup of Gondwana are summarized in more detail by Crame (1999) and are therefore only briefly reviewed here. In Jurassic times Laurasia and Gondwana were still connected, but India had already moved northwards close to its present position by about $135 \mathrm{Ma}$ ago according to Kennett (1977), Shackleton and Kennett (1975) and Shackleton and Boersma (1981). The breakup of Gondwana continued in the Cretaceous period with the isolation and northward movement of Africa, completed about $90 \mathrm{Ma}$ ago. After the first rifting between Antarctica and Australia about 100 Ma ago (e.g. Lawver et al., 1992; Crame, 1999), full deepwater separation between Australia and Antarctica subsequently enhanced the establishment of a cur- 
rent around the eastern part of the Antarctic in the beginning of the Eocene until the Oligocene $(\approx 55$ $35 \mathrm{Ma}$ ago) (Kennett et al., 1975). The subsequent establishment of the Circumpolar Current was at that time only interrupted by the existance of the land connection between the Antarctic Peninsula and South America (compare Lawver et al., 1992; Storey, 1996; Crame, 1999). However, this current probably already supported the cooling of the ocean water and the subsequent isolation of Antarctica (compare Huber and Watkins, 1992). With the opening of the Drake Passage (some 28 to $23 \mathrm{Ma}$ ago) and the establishment of the Scotia Arc the circumpolar current became gradually effective and this led to another decline in the Antarctic surface water temperature (Crame, 1992; 1994; Clarke and Crame, 1992). The final formation of a deep-sea passage between South America and Antarctica was probably a key event for the evolution of many taxa of these environments, as shown for the Antarctic krill (Euphausia superba and E. crystallorophias) and E. vallentinii from the Subantarctic (Patarnello et al., 1996).

The reconstruction of the development of the Scotia Arc illustrated that in early Cenozoic (about $50 \mathrm{Ma}$ ago), the islands of the Scotia Arc and the South Shetland Islands were situated much closer together, a fact which led to the hypothesis that Antarctica might have been recolonised by some taxa via the Scotia Arc before these islands were disassembled due to the faster movement of the Antarctic plate in clockwise direction (Lawver et al., 1992). However, a schematic illustration of the present condition shows that these islands are separated by deep-sea areas (cf. Hellmer and Bersch, 1985) and this will certainly make active immigration difficult for many shelf species. In comparison the Falkland Islands and South America are connected via the shallow Burdwood Bank. This is certainly also the reason why we find the best agreement in species composition between the Falkland Islands and the Magellan area (compare Brandt et al., 1999). However, if we compare the faunistic similarity of the other islands with the Magellan area, it is interesting to see that at least regarding isopod composition, the South Shetland Islands share as many species (13) with the Magellan area as South Georgia (compare Brandt, 1991: 185).

Shackleton and Kennett (1975), Haq et al. (1987), and Clarke and Crame (1992) have illustrated the history of the Southern Ocean cooling, which is probably correlated first with the separation of
Australia from Antarctica, and later with the completion of the circumpolar current in the area of the Drake Passage. However, Clarke (1990) has calculated that the changes in water temperature were rapid only in geological terms; even the fastest decrease of around 8 degrees in 3 million years is equivalent to only 0.003 degrees every 1000 years, a change which should not have a dramatic impact on the evolution or extinction of species.

\section{SOME CHARACTERISTICS OF ANTARCTIC PERACARIDA}

Of the various taxa of Peracarida, Isopoda and Cumacea are usually very abundant, while Amphipoda tend to be the most speciose (e.g. Bousfield, 1982; Brandt, 1995, 1997; Brandt et al., 1996; Dahl et al., 1976; Dauvin et al., 1995; Poore et al., 1994). These three taxa all live epibenthically, with some species preferring to burrow in the sediment (e.g. the Cumacea). Mysidacea actively filter the water column, especially in the benthic boundary layer, whereas most Tanaidacea belong to the infauna (e.g. Sieg, 1984).

In Antarctic shelf communities sessile suspension feeders, such as Porifera, many species of Cnidaria and Polychaeta, Bryozoa and Ascidiacea are very important in terms of biomass (e.g. Bullivant, 1967; Dayton et al., 1974, 1994; Gutt, 1988; Voß, 1988). These suspension feeders serve as a food source for a number of predatory food specialists, such as Amphipoda (e.g. Coleman, 1989, 1991; Klages and Gutt, 1990). They also serve to increase the habitat heterogeneity due to ecologial niche "fragmentation" (e.g. Arntz et al., 1994), and thus allow a higher number of smaller species to settle in small areas, i.e. intensify diversification (e.g. Blackburn and Gaston, 1996).

Dayton et al. (1994: 98) pointed out that the Antarctic seas offer a paradox "in which the water column has sufficient productivity to support large populations of mammals, birds, squids, etc., but the benthic communities are characterized by low growth rates and secondary production". These authors noted that in the Arctic more surface burrowing species such as echiurids, polychaetes, and echinoderms can be found compared to the Antarctic, and they wondered if the Antarctic, though being considerably older than the Arctic, lacks the degree of complexity offered by Arctic habitats (Dayton et al., 1994). This is mainly true for the infauna, but 


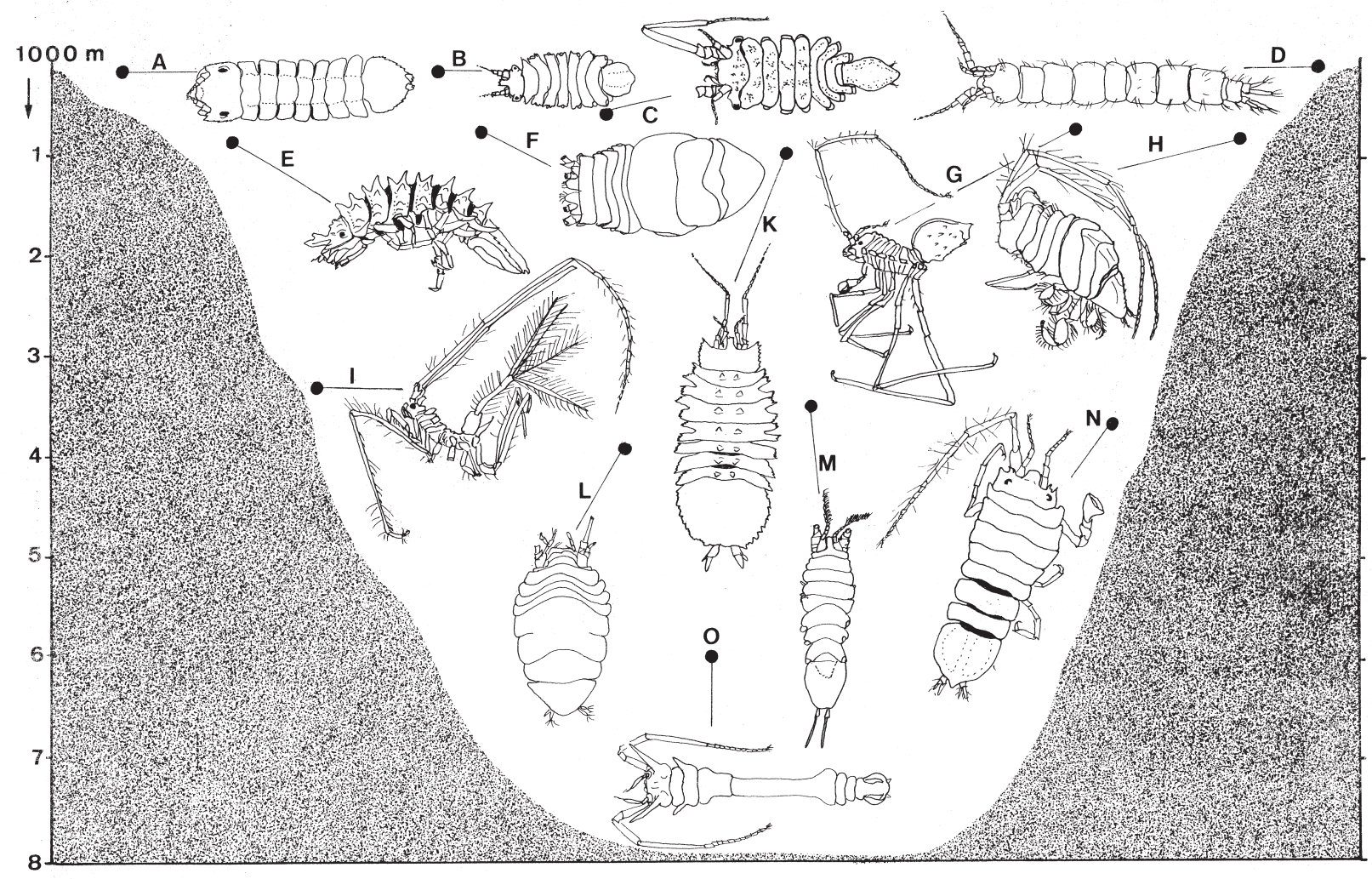

FIG. 1. - Schematic illustration of some genera of Isopoda showing different depth distributions: A) Joeropsis; B) Notasellus; C) Munna; D) Vermectias; E) Ianthopsis; f) Coperonus; G) Munna; H) Echinozone; I) Zoromunna; K) Acanthaspidia; L) Disconectes; M) Paramunnopsis; N) Stenetrium; O) Haplomesus.

not so obvious for the epifauna (e.g. Piepenburg et al., 1997). In the Antarctic, however, the high number of sessile filter feeders (e.g. Moyano, 1996; Pansini and Sarà, 1999) leads to considerable habitat heterogeneity (e.g. Dayton, 1990). It might also be that this rich epifauna reduces significantly the amount of organic particles that can reach the ground (e.g. Brandt, 1995; Brandt et al., 1996; Gutt, 1988; Piepenburg, 1988). This was also presumed for the Antarctic molluscs, as epifaunal Gastropoda are more common than infaunal Bivalvia (Crame, 1997: 2): "the predominance of gastropods over bivalves in the Antarctic molluscan fauna is a reflection of the fact that they are largely an epifaunal group. Many other epifaunal taxa appear to have adapted well to the coarse-grained glacial substrates too, with sessile filter and particle feeders being especially prominent". The dominance of filter feeding animals might also be a potential reason for the apparent scarcity or total absence of crabs, lobsters, stone crabs, galatheid shrimps, and others. Moreover these taxa are not specialised to feed on suspension feeders, as are many larger Peracarida, such as amphipods (e.g. Coleman, 1989, 1991). Perhaps some of the Peracarida occupy the ecological niche vacated at some time in the Cenozoic by the Decapoda (e.g. Feldmann, 1986; Feldmann and Tshudy, 1989; Feldmann et al., 1993; Feldmann and Crame, submitted; Zinsmeister and Feldmann, 1984; Arntz et al., 1997). The most recent fossil decapod from the Pliocene was found in the Vestfold Hills, East Antarctica (Feldmann and Quilty, 1997).

Peracarida are also an interesting macrofaunal taxon because they occur in almost any terrestrial and marine environment on earth, from shallow shelf sites down to the deep sea, and they are the most speciose macrobenthic taxon in the Antarctic, probably even in the whole Southern Ocean (De Broyer and Jazdzewski, 1996). Many taxa of these crustaceans show a wide vertical distribution. For example, among the Isopoda (Fig. 1) some species are true shelf organisms or are adapted to the deep sea, whereas many others reveal an extended degree of eurybathy (Brandt, 1991; Winkler, 1994a; compare also Brey et al., 1996), what might have facilitated emergence of some taxa onto the Antarctic continental shelf.

From the fact that the Peracarida are very important in terms of both species richness and abundance (e. g. Jazdzewski et al., 1992), the ques- 
tion arises: what are their advantages that enable them to thrive in Antarctica? One of the most important synapomorphies they share is the possession of a marsupium into which females release the eggs and where usually the first and second manca stage develop; this is a mode of reproduction which is considered to be a preadaptation to short seasonal plankton blooms in an environment of low, growth-delaying temperatures (e.g. Picken, 1980; compare also White, 1984). The life history pattern of most species of Peracarida follows rules of k-strategy: longevity, large body size, a lower metabolic rate, low fecundity, delayed maturation, and low, prolonged reproductive rates (Arntz et al., 1994; Luxmore, 1984; Wägele, 1987, 1988, 1990, 1992). However, according to Belman (1975) the isopod Glyptonotus antarcticus grows faster. Glyptonotus antarcticus is known to be a stenothermal giant (k-strategy), which dies above $6^{\circ} \mathrm{C}$ like most Antarctic invertebrates (White, $1970,1975)$. The possession of very good chemoreceptors (aesthetascs) is important for scavengers, but also predators (De Broyer, 1995) as well as herbivorous or detritus feeders in a strongly seasonally pulsed environment. Aesthetascs are present in all crustaceans, however, maybe other invertebrate taxa do not possess such efficient chemoreceptors and therefore might be less competitive than Peracarida. The good swimming capacity of at least amphipods, isopods and mysids might also help species of these taxa to reach food sources before other, slower, taxa (like echinoderms, molluscs, or most polychaetes) arrive.

\section{PRESENT KNOWLEDGE OF THE BIODIVERSITY OF PERACARIDA IN THE SOUTHERN OCEAN}

Until now only a few extensive accounts of the biodiversity of peracarid crustaceans are available for the Southern Ocean. Reference to the Antarctic means the area south of the Antarctic Convergence. De Broyer and Jazdzewski (1996) estimated 531 amphipod species in the high Antarctic, 821 if the whole Southern Ocean is considered. Of the 56 species of Cumacea, $77 \%$ are endemic to the Antarctic, while of 365 species of Isopoda (19 new Antarctic species were recorded since Brandt's account of 1991), $88 \%$ are endemic. If the southern Magellan area (i.e. only the Magellan Straits, Beagle Channel, southern tip of South America, the
TABLE 2. - Numbers of species (S) and percentages of endemism (E) of the five Antarctic peracarid taxa, in comparison with other crustacean taxa Decapoda and Ostracoda. A - Antarctic region (south of Antarctic Convergence), M - Magellan region, Mi - including southern part of Magellan region, SO - Southern Ocean (to Subtropical Convergence)*. Sources: 1 De Broyer and Jazdzewski, 1996; 2 Mühlenhardt-Siegel, this vol.; 3 Brandt, this paper; 4 Brandt et al., 1998; 5 Schmidt, 1999; 6 Hartmann, 1990, 1997, pers. comm.; 7 Gorny, 1999; Arntz et al., 1999.

\begin{tabular}{|c|c|c|}
\hline & $\mathrm{S}$ & $\mathrm{E} \%$ \\
\hline Amphipoda ${ }^{1}$ & $\begin{array}{l}531(\mathrm{~A}) \\
174(\mathrm{M}) \\
821(\mathrm{SO})\end{array}$ & $\begin{array}{l}72 \\
48 \\
76\end{array}$ \\
\hline Cumacea $^{2}$ & $\begin{array}{l}56(\mathrm{~A}) \\
33(\mathrm{M}) \\
87(\mathrm{SO})\end{array}$ & $\begin{array}{l}77 \\
52 \\
? ?\end{array}$ \\
\hline Isopoda $^{3}$ & $\begin{array}{l}365(\mathrm{~A})^{* *} \\
123(\mathrm{M}) \\
427(\mathrm{Mi}) * * *\end{array}$ & $\begin{array}{r}88 \\
50 \\
>60\end{array}$ \\
\hline Mysidacea ${ }^{4}$ & $\begin{array}{l}37(\mathrm{~A}) \\
31(\mathrm{M}) \\
59(\mathrm{SO}) * * * *\end{array}$ & $\begin{array}{l}51 \\
48 \\
58\end{array}$ \\
\hline Tanaidacea $^{5}$ & $\begin{array}{c}50(\mathrm{~A}) \\
36(\mathrm{M}) \\
127(\mathrm{SO})\end{array}$ & $\begin{array}{l}30 \\
27 \\
59\end{array}$ \\
\hline Ostracoda ${ }^{6}$ & 323 (SO) & $>90$ \\
\hline Decapoda $^{7}$ & $\begin{array}{c}23+(\mathrm{A}) \\
61(\mathrm{M}) \\
132(\mathrm{SO})\end{array}$ & $\begin{array}{l}0.4 \\
? ? \\
? ?++\end{array}$ \\
\hline
\end{tabular}

*Delimitations of Antarctic, Subantarctic and Magellan regions differ between some authors (compare original papers cited in table). ** Includes Subantarctic but not Magellan *** Another SO figure published by Winkler (1994 a,b) is $492 \mathrm{spp}$. (cf. text). **** Only Antarctic + Subantarctic (probably underestimate). +Includes benthic and pelagic shelf and slope species, but excludes 6 deep-sea species. ++ The endemism value for South American antiboreal benthic decapods is $37 \%$ (29 of 79 spp.).

Falkland Islands and Burdwood Bank) is included in this calculation, 427 species of Isopoda are known from this area. 59 Antarctic and Subantarctic Mysidacea have been described. A total of 51\% of 37 Antarctic species of this taxon are endemic (Brandt et al., 1998), and the rate of endemism for the 50 species of Antarctic Tanaidacea (30\%) is even lower (Schmidt, 1999). According to Sieg (1988), endemisms differ between the West and East Antarctic. A comparison with other, non-peracarid crustaceans shows that the Ostracoda are more speciose, with 323 species in the Southern Ocean, than the Decapoda with 132 species, and only 23 species in the high Antarctic of which a single one is endemic (Gorny, 1999; Arntz et al., 1999) (Table 2). Stomatopods seem to be missing altogether in Antarctic waters. 


\section{ON THE ORIGIN OF ANTARCTIC PERACARIDA}

Sieg (1988) published the first important account of Antarctic Tanaidacea, in which he not only listed all known Antarctic species, but also contributed significantly to the Antarctic zoogeography and evolution of the Tanaidacea (see also Sieg, 1983, 1984, 1986). Sieg (1988) was also the first person to question the age and origin of the crustacean fauna of the Antarctic continental shelf. He explained that the fossil record of the Tanaidacea leads to the assumption that all recent families must have evolved before the Eocene; therefore all species had the chance to colonize the Antarctic shelf area. However, a detailed phylogenetic analysis of the Tanaidacea led Sieg (1988) to conclude that the Antarctic tanaidacean fauna is represented by phylogenetically young taxa only. While in West Antarctica more members of the shallow-water families Apseudidae, and the phylogenetically slightly older Tanaidae (for which Sieg [1986] documented geographic vicariance) and Leptocheliidae were found, in East Antarctica more species exist (e.g. of the Neotanaidae). These probably colonized Antarctica via deep-sea emergence, as only two species with eyes were found. Sieg (1988) concluded that all species of the Tanaidacea must have been eliminated during the Cenozoic climatic deterioration. Species of the phylogenetically primitive Tanaidae and Paratanaidae survived the maximal glaciation in Subantarctic areas, or in the Magellan region, until the retreat of the ice allowed them to recolonize West Antarctica. Sieg (1988) believed that other available information on Crustacea, especially on Ostracoda, Decapoda and Isopoda, supports his interpretation, and therefore concluded that the recent Antarctic crustacean fauna must be comparatively young.

Nevertheless, a slight contradiction in Sieg's (1988) arguments should be pointed out. In the beginning (p. 364) he summarized "surprisingly in the West Antarctic some primitive phylogenetic taxa occur, which are not recorded from the East Antarctic... the East Antarctic fauna is more likely that of the deep sea", whereas later on page 375 he said "though the present tanaidacean fauna consists of only phylogenetically derived families of the Tanaidomorpha, it is characterized by a relatively high heterogeneity, i.e. many phylogenetically nonrelated families occur with few species. Therefore an immigration of few "founder species" and a later radiation to the present species richness can be excluded...".

In the following paper Sieg's arguments will be reconsidered in the light of more recent data.

\section{Ostracoda}

Benson (1975) pointed out that, although the data on Antarctic Ostracoda were incomplete, it was still possible to postulate a change in species composition between the Eocene and Oligocene. Moreover, the Antarctic Mydocopina showed (like the Tanaidacea) only a few similarities in species composition with South America, and Australia and New Zealand share no faunistic elements with Antarctica. The same relationships were expected for the Podocopa, which were not studied at that time.

A most extensive study by Hartmann (1990, 1997) showed that most of the 323 known Southern Ocean ostracod species are benthic (only the Halocyprida are pelagic), the Podocopa are more speciose in the Antarctic than the Mydocopa. The Podocopa are mainly littoral species and known from Oligocene sediments of the Polonez Cove Formation (King George Island) (Blaszyk, 1987; Hartmann, 1990, 1997). Some of these Antarctic species have apparently not changed since the Oligocene; others show very close similarities to the Antarctic Oligocene ostracod fauna. These findings prove that the Ostracoda cannot have been completely eliminated in the Antarctic during the Cenozoic climatic deterioration. Besides the fossil records, the presence of eyes in some shelf species favours the hypothesis of an ancient littoral Antarctic ostracod fauna (Hartmann, 1990, 1997) (Table 3).

\section{Decapoda}

The decapods were also known from fossil records in the Antarctic and support the theory of a "Weddellian Province" in the Eocene (Zins-

TABLE 3. - Species numbers of the most important Antarctic Ostracoda (Hartmann, 1990, 1997).

\begin{tabular}{lrl}
\hline Mydocopa & 74 & mostly benthic \\
Halocyprida & 60 & exclusively pelagic \\
Cladocopa & 7 & exclusively benthic \\
Podocopa* & 182 & mostly benthic \\
Known Southern Ocean species & 323 & \\
\hline
\end{tabular}

* mainly littoral, fossil record since Oligocene 
meister, 1982a, b). All of the Cenozoic genera, such as Lyreidus, Chasmocarcinus, Fusitriton and others, did not survive the Eocene climatic changes, nor do we know of any recent descendants of the early Miocene nephropid lobster Hoploparia (Feldmann and Crame, 1998), or the homolodromiid crab Antarctidromia (see Crame, 1999). Today, only few Decapoda occur on the high Antarctic shelf (11 benthic and 12 pelagic species, see Table 2, Gorny, 1999), and these species cannot be derived from the Eocene taxa. 132 species of Reptantia and Natantia are known for the whole Southern Ocean (see Gorny, 1999). It is likely that the recent decapod fauna has recolonized the Antarctic shelf from some form of Neogene refugium (e.g. Crame, 1992; Feldmann and Tshudy, 1989; Zinsmeister and Feldmann, 1984).

\section{Mysidacea}

Interestingly, the fauna of Mysidacea known from the Antarctic (37 species) is more diverse than that of the Decapoda (Table 4); 59 species of Mysidacea are known from the Southern Ocean (Brandt et al., 1998), which renders it unlikely that the pelagic or benthopelagic life style of the Decapoda should be the reason for their scarcity in Antarctica; maybe the improved brood protection of the mysids - referred to above - is at least a partial reason for their greater success in this environment. As none of the recent Antarctic Mysidacea is a "true" deep-sea species, a recolonization of the Antarctic Mysidacea from the deep sea is unlikely (Brandt et al., 1998). It is more probable that these Peracarida colonised Antarctica from the Atlantic, for example via the Scotia Arc region or from the Pacific (Wittmann, 1991; compare recent zoogeographic distribution in Brandt et al., 1998).

TABLE 4. - Number of species of the Weddell Sea mysid genera, sampled by Wittmann (1991).

most important genera species

Hansenomysis

Amblyops

Pseudomma

Mysidetes

Antarctomysis

Heteromysis

Weddell Sea species

\section{Cumacea}

The Antarctic Cumacea show a high percentage of endemism and a close relation to the deep-sea fauna; however, differences are also recorded in species composition between West and East Antarctica (Mühlenhardt-Siegel, 1999; Dell, 1972; Lomakina, 1968; Jones, 1971). This does not necessarily mean that the Antarctic cumacean fauna is ,young“. Mühlenhardt-Siegel (1999) recalculated the values of these authors and integrated new records (e.g. Ledoyer, 1990 a, b). At present, 77\% endemism occurs in the Sub- and High Antarctic, and a detailed analysis of the different Antarctic regions (compare Brandt et al., 1999) reveals no differences between the West and East Antarctic cumacean fauna. On the contrary, most of the species seem to be distributed circumantarctically, as is also true for the Mysidacea (Brandt et al., 1998).

\section{Amphipoda}

Watling and Thurston (1989) referred to the Antarctic as an "evolutionary incubator" after investigating the phylogeny of the amphipod family Iphimediidae. The latter was later subdivided by Coleman and Barnard (1991) into the Acanthonotozomellidae, Diwiidae and Odiidae, while the Acanthonotozomatidae, Amathillopsidae, Astyridae, Epimeriidae (= Paramphitoidae), Ochlesidae and Stilipedidae were rediagnosed. "The presence of primitive iphimediid genera in the northern hemisphere and in southern Africa, as well as in the Antarctic, suggests that the family was widespread before the thermal isolation of the Antarctic continent began, and that there are only few remnants of that early distribution left" (Watling and Thurston, 1989: 304). As there is no fossil evidence, the exact onset of the major diversification of species of this family is not known. However, it is likely that an intensified speciation began some time after the initiatial breakup of Gondwana, and that once the Antarctic began to cool some $38 \mathrm{Ma}$ ago, a radiation of the iphimediids occurred in the Southern Ocean. This event might have coincided with the onset of cold water formation, beginning in the Atlantic sector of the Southern Ocean at the end of the Eocene (Watling and Thurston, 1989; Kennett, 1977; Kennett and Stott, 1991; Schnitker, 1980).

The most detailed analyses of the biodiversity and endemicity of Antarctic Amphipoda have been carried out by De Broyer and Jazdzewski (1993; 
1996), and by Jazdzewski et al. (1995). In the Antarctic region 531 species (72\% endemism) of Amphipoda are recorded until now; if the Subantarctic region (complete Southern Ocean) is included then De Broyer and Jazdzewski's list comprises 821 species (76\% endemism for all, benthic and pelagic amphipods). These high species numbers show that the Amphipoda are the most speciose peracarid taxon, maybe even generally the most diverse taxon in the Antarctic. The presented rates of endemism, however, show (compare Table 2) that earlier calculations (e.g. Knox, 1977; Knox and Lowry, 1977) were overestimations, whereas the number of species is much higher than recently published (Dayton et al., 1994). Sampling during the expedition ANT XV-3 (January to March 1998, Weddell Sea) with RV Polarstern already brought more than 30 new species on deck (De Broyer, pers. comm.), documenting that Antarctic amphipod species numbers are underestimations.

\section{Isopoda}

Regarding the possible origin of Antarctic Isopoda, Sieg (1988) cited Kussakin (1973) and Menzies et al. (1973), both of whom favoured the hypothesis that the Antarctic taxa are the ancestors of the modern deep-sea species. In contrast, Hessler and Thistle (1975), Hessler and Wilson (1983), and Hessler et al. (1979) all assumed that the Antarctic Isopoda were derived from primitive deep-sea species. Following the latter argument, Sieg (1988) concluded that all known Antarctic taxa of this order are phylogenetically derived.

This generalized conclusion led to a detailed phylogenetic investigation of species of some important families of the Isopoda, and to a hypothesis concerning the phylogenetic biogeography of the Serolidae and Arcturidae (Brandt, 1991, 1992; Wägele, 1994). These two monophyletic isopod families (Wägele, 1989) are the most speciose ones, apart from the suborder Asellota (Wägele and Brandt, 1992), which probably comprises many paraphyletic taxa. The vertical distribution of the isopod families and genera in the Southern Ocean shows that most genera are distributed on the continental shelf, many even in the first $300 \mathrm{~m}$ of depth (Brandt, 1991: 110, 113).

Since the extensive account of Antarctic Isopoda given by Brandt (1991), 19 new species have been recorded from the high Antarctic, and 14 new

TABLE 5. - New species of Antarctic (•) and Magellan Isopoda (since 1991).

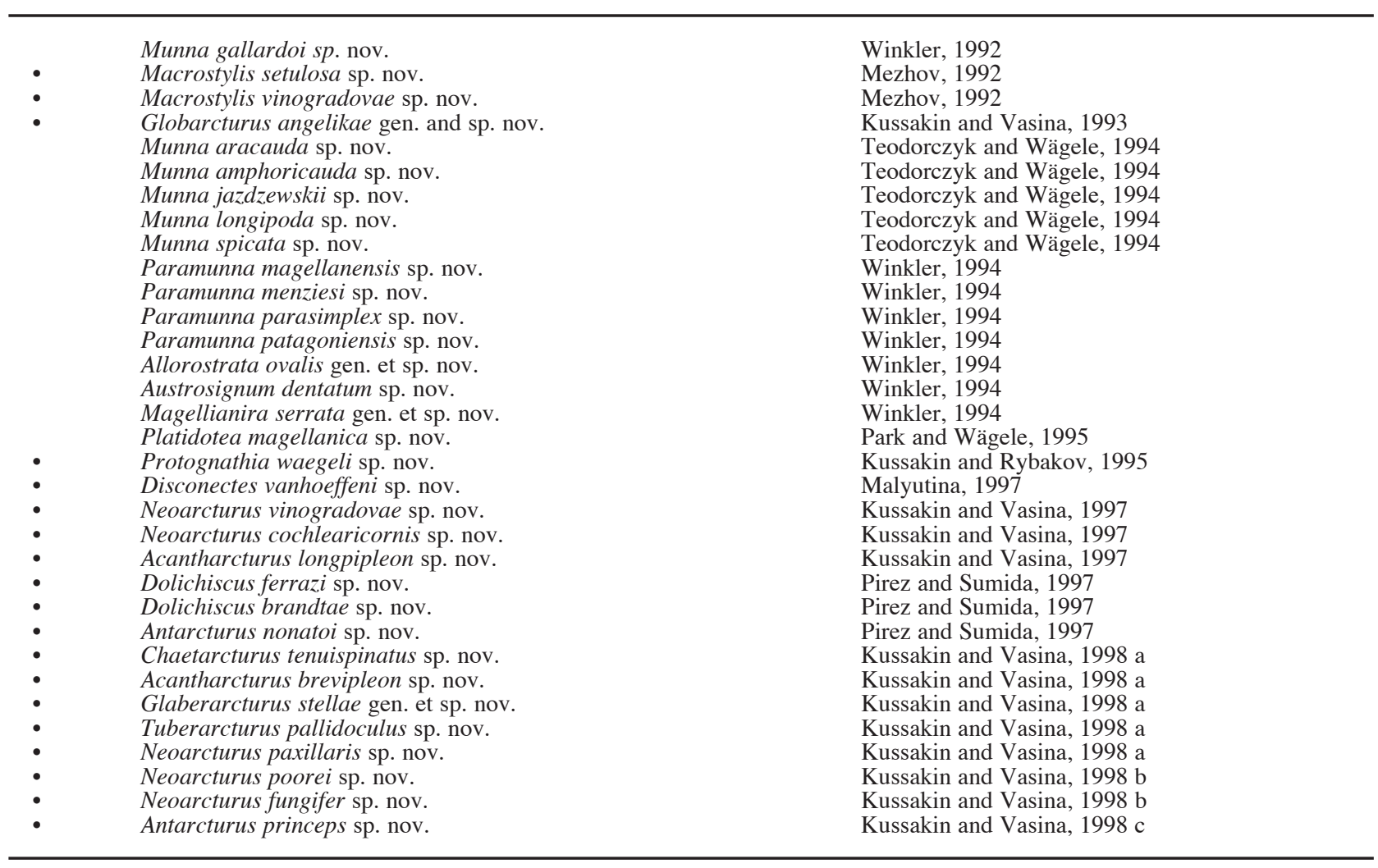


species have been recorded for the Magellan Straits (Table 5).

De Broyer and Jazdzewski (1996) do not include the Magellan region in the Subantarctic, which in their opinion begins around South Georgia and extends further via the Scotia Arc. Following this scheme, 365 species of 125 genera and 25 families of Isopoda are known for the Sub and High Antarctic at present. A total of $70 \%$ of these species (and about $60 \%$ of the genera) occur on the continental shelf.

If the southernmost area of the Magellan region (Magellan Strait and Beagle Channel) is included in the calculations, a total of 427 species of Isopoda for the area is reached. Interestingly the Magellan region is characterized by a higher rate of endemicity than the High Antarctic (in the Magellan area we have about $40 \%$ endemism, in the East Antarctic only about 30\%) (see Brandt et al., 1999; Table 6). Winkler (1994a, 1994b) also published a detailed account of Magellan and Antarctic Isopoda from a selected sector $\left(35^{\circ} \mathrm{S}\right.$ to $80^{\circ} \mathrm{S}$ and $5^{\circ} \mathrm{W}$ to $\left.85^{\circ} \mathrm{W}\right)$; here he recorded a total of 492 species of Isopoda. This author found the Scotia Ridge system and South America to be the region with most genera, being characterized by a high percentage of cosmopolitans. Winkler (1994a) concluded that the species of these genera must have a high physiological plasticity, and thus the adaptive potential to colonise different environments such as the Antarctic and more northern habitats of South America.

Analyses of the phylogenetic biogeography of the Isopoda (Brandt, 1991, 1992; Wägele, 1994) have led to the following hypotheses for the colonization of the Antarctic by the Arcturidae and Serolidae. Within the Arcturidae the most primitive members of the family are found in the southern hemisphere, especially along the southern margins of the former Gondwana continents, i.e. southern Africa, Australia and South America (Wägele, 1989; Brandt, 1991). The Holidotheinae, the most primitive subfamily, is found in South Africa, the Pseudidotheinae in Patagonia, the South Shetland Islands, the Crozet Islands, Kerguelen Islands and New Zealand, and the Xenarcturinae in Patagonia (Brandt, 1991). The unlinked distribution of the Pseudidotheinae can only be explained by continental drift vicariance. Because of the zoogeography of these phylogenetically more primitive subfamilies of the Arcturidae, it is likely that the ancestors of the Arcturinae were also restricted to the coasts of southern Gondwana. From a common ancestor of
TABLE 6. - Isopoda of the Antarctic and the Magellan area, species numbers, number of endemics and percentage of endemism.

\begin{tabular}{lrrr}
\hline Region & sum S & endemics & \% endemism \\
\hline Magellan region & & & \\
Magellan area & 101 & 40 & 40 \\
Falkland I. & 70 & 22 & 31 \\
& & & \\
Subantarctic & 49 & 9 & 18 \\
South Georgia & 16 & 5 & 31 \\
South Sandwich I. & 26 & 2 & 8 \\
South Orkney I. & 94 & 26 & 28 \\
South Shetland I. & 31 & 5 & 16 \\
Crozet I. & 80 & 28 & 35 \\
Kerguelen I. & 10 & 1 & 10 \\
Macquarie I. & 5 & 1 & 0 \\
Auckland I. & 7 & 0 & \\
Campbell I. & & & \\
& & 2 & 5 \\
High Antarctic & 40 & 13 & 30 \\
Bellingshausen Sea & 68 & 34 & \\
Weddell Sea & 39 & & \\
Ross Sea & 11 & & \\
East Antarctic & & & \\
$\quad$ & & & \\
\hline
\end{tabular}

these subfamilies, primitive Arcturinae probably already evolved in Antarctica, and experienced an adaptive radiation. Some derived genera may also have evolved already in the Southern Ocean, from where they colonized all world oceans including the Arctic region (and some species of Neastacilla have colonized the deep sea, like, for example, from the Atlantic, the Antarctic or the Kermadec Trench). G. Poore (pers. comm., 1996) has suggested that a new family, the Antarcturidae, will probably have to be established in future to accomodate the enormous amount of new and interesting species in the Australian arcturid fauna.

The Serolidae show a very similar pattern in their colonization of Antarctica. Within the Sphaeromatidea, the Plakathriidae are the most primitive family. The Bathynataliidae are the sister group of the Serolidae (Wägele, 1989).

The general distribution of the Sphaeromatidea shows that the most primitive taxa are again distributed around the southern margins of the former supercontinent Gondwana. The Serolidae can be derived from a common ancestor with the Bathynataliidae and Plakathriidae. The species of the Bathynataliidae occur in South Africa and Australia, the Plakathriidae in southern Patagonia, South Georgia, the South Orkney and South Shetland islands and around New Zealand (probably due to continental drift vicariance). Therefore it is most likely that the ancestor of the Antarctic Serolidae also already existed in southern Gondwana. Some primitive gen- 
era of the Serolidae probably already evolved along the coast of southern Gondwana before all of the continents had separated from Antarctica. In Antarctica, the species of the Serolidae have radiated, and some specialized and derived genera also occur in Australia, New Zealand, the Kerguelen region or along the east coast of South America. Some also immigrated into the East Pacific, probably before the progressive establishment of the Panama land bridge between 9.2-3.1 Ma ago (Crame, 1994). Only very few species have been recorded from North America. The species of the deep-sea genera Atlantoserolis, Glabroserolis, and Caecoserolis can probably be derived from East-American ancestors.

Based on descriptions of some new genera of the Serolidae, Wägele (1994) presented a new dendrogram, and suggested that the Serolidae most likely evolved between 25-30 Ma ago (i.e. before the Drake Passage developed and South America separated from Antarctica). Following Wägele's (1994) argument, the ancestor of the Serolidae must also have settled in the former Gondwana area, but the descendant Antarctic species evolved only after the gradual establishment of the Drake Passage, i.e. approximately completed during the last 28-20 Ma. Centres of radiation were the Atlantic coast of South America, the Antarctic continental shelf and shallow habitats along the Australian coast. Vicariance events resulted in some species of the genera Heteroserolis and Serolina being restricted to Australia in their distribution (see also Brandt, 1991).

Some other isopod families, e.g. the Acanthaspidiidae have also likely evolved in the Antarctic (Brandt, 1991: 159 ff.), as the most primitive species are distributed circumantarctically, whereas the more derived ones have probably submerged into the deep-sea. Within the Acanthocopinae (Munnopsidae, compare Wägele, 1989), the Antarctic, southern Patagonia, the South Shetland Islands and the southern Weddell Sea are the main distributional centres, suggesting also an evolution of this subfamily in the Antarctic. Although the isopod family Munnidae has a worldwide distribution, it should be noted that the genera Astrurus, Echinomunna, and Zoromunna are endemic for the Antarctic, where they have probably evolved from ancestors of the genus Munna, which occurs at all depths, and has some cosmopolitan species, and also some circumantarctic ones. It is possible that the Munnidae are a very ancient family which already existed before Pangaea separated into Laurasia and Gondwana (Brandt, 1991: 172), or, alternatively, the species of Munna have only experienced a radiation in more recent times. However, Munna is probably phylogenetically older than Zoromunna, Echinomunna, and Astrurus. These deep-sea genera are most probably descendants of shelf ancestors, and illustrate an example of polar submergence.

The origin of the Paramunnidae is not well known. This family supposedly also radiated in Antarctica or in southern Gondwana (compare Kussakin, 1973: 24 ff; Wilson, 1980: 231; Winkler, 1994a: 123). The deep-sea species can probably be derived from shelf progenitors (polar submergence). Most species of the asellote isopod families Pleurocopidae, Haplomunnidae and Dendrotionidae occur in the southern hemisphere, not only in Antarctica, but also in South America, Australia, and New Zealand. It is possible that the species of these families developed shortly before the separation of Australia from Gondwana from ancestory of the recent Munnidae and Paramunnidae, which are distributed worldwide and are very probably phylogenetically ancient taxa.

An origin of the Antarctic Nannoniscidae can most probably be derived from deep-sea progenitors of the northern hemisphere (Brandt, 1991: 175). The deep-sea family Desmosomatidae is the sister group of the Nannoniscidae. The origin of this family also most probably lies in the northern hemisphere. The Antarctic species probably evolved from deep-sea ancestors in the North Atlantic and later, probably supported by the circumpolar current, been distributed into East Antarctica.

The Ischnomesidae also evolved in the northern hemisphere and have only a few Antarctic species. The genus Haplomesus is mainly distributed in the Arctic, with only a few species in the South Atlantic, off South Africa. It is likely that the primitive Ischnomesidae originated in the North Pacific (Arctic). The development of species of this family in the Antarctic most probably happened via the deep sea Atlantic. However, as the Atlantic only began to open in Jurassic times and its establishment was not finished before the end of the Cretaceous, a migration of the genus Haplomesus into the Antarctic via the Atlantic deep sea could not have happened before Late Cretaceous times. Winkler (1994a) also pointed out that the recent distributional patterns of isopod species from South America and Antarctica show that an exchange of fauna might be independent of former palaeogeographic constraints. He suggested that the Isopoda have not only reached the 
Antarctic via the Scotia Arc system. In particular, Winker (1994a) showed that the colonization of Isopoda at South Georgia and the South Sandwich Islands probably occurred independently from the separation of South America from the Antarctic. This is so because many isopod species of these islands probably originated and radiated out before the Cretaceous, or even later. Moreover, a recolonization via the Scotia Arc must have been difficult, as the various species could only have reached Antarctica against the strong currents of the West Wind Drift, once they had arrived at the South Sandwich Islands. It might be possible to reach these islands on natural floats, such as algae or wood, but it is certainly not easy to reach the South Orkney Islands against the prevailing current direction!

\section{CONCLUSION}

Peracarida are one of the most successful macrobenthic taxa in the Antarctic, probably in the whole Southern Ocean. The reasons for their success in this environment are complex and certainly manifold (see introduction). Besides having experienced a comparatively long evolutionary history, Antarctic Peracarida were obviously biologically and physiologically "preadapted to" the slowly changing and cooling environment. Certainly, one of their major advantages is the possession of a marsupium (brood protection) and in general a life history pattern of species described as K-strategy (e.g. Arntz et al., 1994; 1997). In parallel to the evolutionary success of the Peracarida, many higher Malacostraca, i.e. Decapoda became extinct, probably since the beginning of the Eocene until Pliocene times (e.g. Feldmann and Tshudy, 1989; Feldmann and Quilty, 1977; Feldmann and Crame, 1998), offering even more ecological niches for the evolving new Peracarida in the course of the Cenozoic climatic deterioration.

A faunistic inventory of each described peracarid taxon has now been achieved for all Antarctic supraorders (e.g. Sieg, 1988; Brandt, 1991; MühlenhardtSiegel, 1999; De Broyer and Jazdzewski, 1993, 1996; Brandt et al., 1998), yielding at least 1500 species of Southern Ocean Peracarida (compare Table 2).

Analyses of the phylogeny and phylogenetic biogeography of many taxa of the Peracarida, however, urgently need to be done in order to trace the potential origin of more peracarid families.
Up to the present it can be demonstrated that at least the Ostracoda, some species of the Iphimediidae (Amphipoda), and the isopod families Serolidae and Arcturidae are not young, as generally hypothesized by Sieg (1988) for the Antarctic Crustacea, but experienced an intense radiation in the Southern Ocean through the Cenozoic era.

Sieg (1988) thought that phylogenetically old taxa of the Tanaidacea recolonized West Antarctica in the Neogene. However, how can one be sure that these taxa might not have survived the ice ages in refugia on the Antarctic shelf, or even further down the Antarctic continental slope (we do know now that many Antarctic species show an extended degree of eurybathy, e.g. Brey et al., 1996)? Lipps et al. (1979) found benthic communities under the Ross Ice Shelf, $474 \mathrm{~km}$ off the open sea in a depth of around $600 \mathrm{~m}$. The hole was drilled through a 420 $\mathrm{m}$ thick ice sheet, and cameras and samplers revealed Orchomene sp., Ceratoserolis, fish, bivalves, gastropods, ostracods and foraminiferans. The logical consequence of the tremendous species richness and high degree of endemicity of most benthic life in Antarctica (Arntz et al., 1997) is that many species must have survived the ice ages, some new ones probably even evolved during these environmental changes. Interestingly the epibenthic and infaunal taxa (e.g. Amphipoda, Isopoda, Tanaidacea, Polychaeta, Gastropoda) are characterized by a much higher percentage of endemism (80$90 \%$ ), than the suprabenthically or benthopelagically living taxa (e.g. Mysidacea, Decapoda), which would have had a much better chance to avoid disadvantageous environmental conditions, due to their motility.

Knox and Lowry (1977) and White (1984) illustrated possible pathways of the origins and dispersals of the Antarctic marine fauna. However, they have not taken the submergence of Antarctic taxa into the deep sea into account, which has been documented for some families, like the Raninidae (genus Lyreidus, compare Feldmann, 1992), the Serolidae and Arcturidae, but also for the Anuropidae and Aegidae, some species of the Stenetriidae, and species of the genus Ianthopsis (Acanthaspiidae) (Brandt, 1991).

For most peracarid families their origin and evolution is still dubious and phylogenetic analyses have not been attempted. However, in order to work out more hypotheses on the possible evolution of the Peracarida, it is first necessary to describe the biodiversity and endemicity of different regions, follow- 
ing the detailed analyses of the Antarctic Amphipoda (DeBroyer and Jazdzewski, 1996) and Isopoda (Brandt, 1991). In order to catch a higher number of individuals for these analyses than previously done by means of box corers or the Agassiz trawl with a large mesh size, a standardized, small mesh-sized device, like for example an epibenthic sledge (Brandt and Barthel, 1995), should be used for sampling smaller epibenthic and suprabenthic macrofauna.

\section{A prospect for essential future research activities in the Southern Ocean}

The complementary use of more adequate gear to sample certain size fractions of the benthos, e.g. epibenthic sledges, would yield an increased number of specimens during surveys and improve the quality of faunal analyses. We must start with an extensive assessment of the biodiversity of different areas and taxa of the Antarctic, not only for purposes of natural conservation, but also for future phylogenetic analyses of the "most important taxa" (in terms of species richness). These are essential requirements to elucidate the possible origin of Antarctica's marine fauna. It would be of extraordinary interest to sample a complete transect from the Antarctic shelf (Weddell Sea and/or the Antarctic Peninsula or King George Island) down the slope into the deep sea towards the abyssal plains, in order to study the compositional change. This would help to gain more evidence for polar submergence or emergence processes of the fauna.

\section{ACKNOWLEDGEMENTS}

The author is grateful to the Universidad de Magellanes, Punta Arenas, and to the Alfred Wegener Institute for Polar and Marine Research, Bremerhaven, for the invitation to the workshop, and to all participants for discussions. Drs. W. Arntz, A. Crame, P. Dayton and an anonymous reviewer kindly read and commented on an earlier version of the manuscript.

\section{REFERENCES}

Arntz, W.E. and M. Gorny. - 1991. Shrimp (Decapoda, Natantia) occurrence and distribution in the eastern Weddell Sea, Antarctica. Polar Biol., 11: 169-177.

Arntz, W.E., T. Brey and V.A. Gallardo. -1994. Antarctic zooben- thos. Oceanogr. Mar. Biol.: Ann. Rev. 32: 241-304.

Arntz, W.E., J. Gutt and M. Klages. - 1997. Antarctic marine biodiversity an overview. In: B. Battaglia, J. Valencia and D.W.H. Walton (eds.), Antarctic communities: species, structure and survival, pp. 3-14. Cambridge University Press, Cambridge.

Arntz, W.E., M. Gorny, R. Soto, M.A. Lardies, M. Retamal and I.S. Wehrtmann. - 1999. Species composition and distribution of decapod crustaceans in the waters off Patagonia and Tierra del Fuego, South America. Sci. Mar., 63(Supl. 1): 303-314.

Benson, R.H. - 1975. The origin of the psychrosphere as recorded in changes of deep-sea ostracod assemblages. Lethaia, 8: 69-83.

Belman, B.W. - 1975. Oxygen consumption and ventilation of the Antarctic isopod Glyptonotus. Comp. Biochem. Physiol., 50A: 149-151.

Blackburn, T.M. and J. Gaston. - 1996. A sideways look at patterns in species richness, or why are there so few species outside of the tropics. Biodiv. Lett., 3: 44-53.

Blaszyk, J. - 1987. Ostracods from the Oligocene Polonez Cove Formation of King George Island, West Antarctica. Palaeontol. Pol., 49: 63-81.

Bousfield, E.L. - 1982. Malacostraca. Peracarida. Amphipoda. In: S.P. Parker (ed.), Synopsis and classification of living organisms, pp. 232-293. Mc Graw Hill Book Company, New York.

Brandt, A - 1991. Zur Besiedlungsgeschichte des antarktischen Schelfes am Beispiel der Isopoda (Crustacea, Malacostraca). Ber. Polarforsch., 98: 1-240.

Brandt, A. - 1992. Origin of Antarctic Isopoda (Crustacea, Malacostraca). Mar. Biol., 113: 415-423.

Brandt, A. - 1995. The peracarid fauna (Crustacea, Malacostraca) of the Northeast Water Polynya, off Greenland, documenting close benthic-pelagic coupling. Mar. Ecol. Prog. Ser., 121: 3951.

Brandt, A. - 1997. Abundance, diversity and community patterns of epibenthic- and benthic-boundary layer peracarid crustaceans at $75^{\circ} \mathrm{N}$ off East Greenland. Polar Biol., 17: 159-174.

Brandt, A. and D. Barthel. - 1995. An improved supra- and epibenthic sledge for catching Peracarida (Crustacea, Malacostraca). Ophelia, 43: 15-23.

Brandt, A., S. Vassilenko, D. Piepenburg and M. Thurston. - 1996. The species composition of the peracarid fauna (Crustacea, Malacostraca) of the Northeast Water Polynya (Greenland). Medd. Groe. Biosci., 44: 1-30.

Brandt, A., U. Mühlenhardt-Siegel and V. Siegel. - 1998. An account of the Mysidacea (Crustacea, Malacostraca) of the Antarctic and Subantarctic Ocean. Antarct. Sci., 10 (1): 3-11.

Brandt, A.,K. Linse and U. Mühlenhardt-Siegel. - 1999. Biogeography of Crustacea and Mollusca of the Magellan and Antarctic regions. Sci. Mar., 63(Supl. 1): 383-389.

Brey, T., C. Dahm, M. Gorny, M. Klages, M. Stiller and W. Arntz. - 1996. Do Antarctic benthic invertebrates show an extended level of eurybathy? Antarct. Sci., 8 (1): 3-6.

Bullivant, J. S. - 1967. Ecology of the Ross Sea benthos. Bull. N. Z. Dept. Sci. Ind. Res., 176: 49-75.

Clarke, A. - 1990. Temperature and Evolution: Southern Ocean cooling and the Antarctic marine fauna. In: K. R. Kerry and G. Hempel (eds.), Antarctic Ecosystems, pp. 9-22. Springer Verlag, Heidelberg.

Clarke, A. and J.A. Crame. - 1992. The Southern Ocean benthic fauna and climate change: a historical perspective. Phil. Trans. R. Soc. Lond., B 338: 299-309.

Coleman, C.O. - 1989. On the nutrition of two Antarctic Acanthonotozomatidae (Crustacea, Amphipoda). Gut contents and functional morphology of mouthparts. Polar Biol., 9: 287-294.

Coleman, C.O. - 1991. Comparative fore-gut morphology of Antarctic Amhipoda (Crustacea) adapted to different food sources. Hydrobiol., 223: 1-9.

Coleman, C.O. and J.L. Barnard. - 1991. Revision of Iphimediidae and similar families (Amphipoda, Gammaridea). Proc. Biol. Soc. Wash., 104: 253-268.

Crame, J.A. - 1992. Evolutionary history of the polar regions. Hist. Biol., 6: 37-60.

Crame, J.A. - 1994. Evolutionary history of Antarctica. In: G. Hempel (ed.), Antarctic Science, pp. 188-214. Springer Verlag, Heidelberg.

Crame, J.A. - 1997. An evolutionary framework for the polar regions. J. Biogeography, 24: 1-9.

Dahl, E., L. Laubier, M. Sibuet and J.O. Strömberg. - 1976. Some quantitative results on benthic communities of the deep Norwe- 
gian Sea. Astarte, 5: 61-79.

Dauvin, J.-C., J.-C. Sorbe and J.-C. Lorgere, J.-C. - 1995. Benthic boundary layer macrofauna from the upper continental slope and the Cap Ferret Canyon (Bay of Biscay). Oceanol. Acta, 18 (1): $113-122$

Dayton, P. K. - 1990. Polar benthos. Polar Oceanography, Part B. Chemistry, Biology and Geology, pp. 631-683.

Dayton, P.K., G.A. Robilliard, R.T. Paine and L.B. Dayton. - 1974. Biological accomodation in the benthic community at McMurdo Sound. Ant. Ecol. Monogr., 44: 105-128.

Dayton, P.K., B.J. Mordida and F. Bacon. - 1994. Polar marine communities. Amer. Zool., 34: 90-99.

De Broyer, C. - 1995. Amphipodes lysianassiodes nécrophages des Iles Kerguelen (Crustacea): 1. Orchomenella guillei n. sp.. Bull. Mus. Nat. Hist., Paris (Ser. 4), 7 A, 1: 205-217.

De Broyer, C. and K. Jazdzewski. - 1993. A checklist of the Amphipoda (Crustacea) of the Southern Ocean. Doc. Trav. de L'l. R. Sc. N. B., 73: 1-154.

De Broyer, C. and K. Jazdzewski. - 1996. Biodiversity of the Southern Ocean: towards a new synthesis for the Amhipoda (Crustacea). Boll. Mus. civ. St. nat. Verona, 20: 547-568.

Dell, R. K.1 - 1972. Antarctic benthos. Adv. Mar. Biol., 10: 1-216.

Feldmann, R.M. - 1986. Paleobiogeography of two decapod crustacean taxa in the southern hemisphere: global conclusions with sparse data. In: R. H. Gore and K. L. Heck (eds.): Crustacean Biogeography, pp. 5-19. Acad. Nat. Sci. Philad., Balkema, Rotterdam, Boston.

Feldmann, R.M. - 1992. The genus Lyreidus De Haan, 1839 (Crustacea, Decapoda, Raninidae): systematics and biogeography. $J$. Paleont., 66(6): 943-957.

Feldmann, R.M. and J.A. Crame. - 1998. The significance of a new nephroid lobster from the Miocene of Antarctica. Paleontol. 41: 807-814.

Feldmann, R.M. and P.G. Quilty. - 1997. First Pliocene decapod crustacean (Malacostraca: Palinuridae) from the Antarctic Antarct. Sci., 9: 56-60.

Feldmann, R.M. and D.M. Tshudy. - 1989. Evolutionary pattern in macrourous decapod crustaceans from Cretaceous to early Cenozoic rocks of the James Ross Island region, Antarctica. In: J.A. Crame (ed.), Origin and evolution of the biosphere. Geol. Soc. Spec. Pub., London, 47: 183-195.

Feldmann, R.M., D.M. Tshudy and M.R.A. Thomson. - 1993. Late cretaceous and paleocene decapod crustaceans from James Ross Basin, Antarctic Peninsula. Paleontol. Soc., Mem., 28: 141.

Gorny, M. - 1999. The biogeography and ecology of the Southern Ocean decapod fauna. Sci. Mar., 63(Supl. 1): 367-382.

Gutt, J. - 1988. Zur Verbreitung und Ökologie der Seegurken (Holothuroidea, Echinodermata) im Weddellmeer (Antarktis). Ber. Polarforsch., 41: 1-87.

Haq, B.U., J. Hardenbol, and P.R. Vail. - 1987. Chronology of fluctuating sea level since the Triassic. Science, 235: 1156-1167.

Hartmann, G. - 1990. Antarktische benthische Ostracoden VI. Auswertung der Reise „Polarstern“ ANT VI-2 (1. Teil, Meiofauna und Zehnerserien) sowie Versuch einer vorläufigen Auswertung aller bislang vorliegenden Daten. Mitt. Hamb. Zool. Mus. Inst., 87: 191-245.

Hartmann, G. - 1997. Antarktische und subantarktische Podocopa (Ostracoda). In: J. W. Wägele and J. Sieg (eds.): Synopses of the Antarctic Benthos, pp. 1- 355. Koeltz Scientific Books, Koenigstein.

Hellmer, H.H. and M. Bersch. - 1985. The Southern Ocean. Ber. Polarforsch., 26: 1-115.

Hessler, R.R. and D. Thistle. -1975 . On the place of origin of deepsea isopods. Mar. Biol., 32: 155-165.

Hessler, R.R. and G.D.F. Wilson. - 1983. The origin and biogeography of malacostracan crustaceans in the deep sea. In: R. W. Sims, J. H. Price and P. E. S. Whalley (eds.): The emergence of the biosphere, pp. 227-254. Systematic Association 23.

Hessler, R.R., G.D.F. Wilson and D. Thistle. - 1979. The deep-sea isopods: a biogeographic and phylogenetic overview. Sarsia 64: 76-75.

Huber, B.T. and D.K. Watkins. - 1992. Biogeography of Campanian-Maastrichtian calcareous plankton in the region of the Southern Ocean: Palegeographic and paleoclimatic implications. In: J. P. Kennett and D. A. Warnke (eds.), The Antarctic paleoenvironment: A perspective on global change. Part One, pp. 31-60. Ant. Res. Ser., 56.
Jazdzewski, K., W. Teodorczyk, J. Sicinski and B. Kontek. - 1992. Amphipod crustaceans as an important component of zoobenthos of the shallow Antarctic sublittoral. Hydrobiol., 223: 105117.

Jazdzewski, K., J.M. Weslawski and C. De Broyer. - 1995. A comparison of the amphipod faunal diversity in two polar fjords: Admiralty Bay, King George Island (Antarctic) and Hornsund, Spitsbergen (Arctic). In: K. Jazdzewski, C. De Broyer and J. Stock (eds.): Biology and ecology of amphipod crustaceans. Pol. Arc. Hydrobiol., 42: 367-384.

Jones, N.S. - 1971. The fauna of the Ross Sea. Bull. N. Z. Dep. Sc. Ind. Res., 206: 33-34.

Kennett, J.P. - 1977. Cenozoic evolution of Antarctic glaciation, the Circum-Antarctic Ocean, and their impact on global palaeoceanography. J. Geophys. Res., 82: 3834-3860.

Kennett, J.R., R.E. Houtz, P.B. Andrews, V.P. Edwards, V.A. Gostin, M. Hajos, M.A. Hampton, D.G. Jenkins, S.V. Margolis, A.T. Ovenshire and K. Perch-Nielsen. - 1975. Antarctic glaciation and the development of the circum-Antarctic Current. In: Initial reports of the deep-sea drilling project, U. S. Government Printing Office, Washington DC, Vol. 29: 1155.

Kennett, J.P. and L.D. Stott. - 1991. Abrupt deep-sea warming, palaeoceanographic changes and benthic extinctions at the end of the Paleocene. Nature, 353: 225-229.

Klages, M. and J. Gutt. - 1990. Comparative studies on the feeding behaviour of high Antarctic amphipods (Crustacea) in the laboratory. Polar Biol., 11: 79-83.

Knox, G.A. - 1977. The Antarctic polychaete fauna: its characteristics, distribution patterns and evolution. In: G. A. Llano (ed.): Proc. Third SCAR Symp. Antarct. Biol. Gulf. Publ. Co., Huston, 1111-1126.

Knox, G.A. and J.K. Lowry. - 1977. A comparison between the benthos of the Southern Ocean and the North Polar Ocean with special reference to the Amphipoda and the Polychaeta. In: M. J. Dunbar (ed.): Polar Oceans, pp. 423-462. Arctic Institute of North America, Calgary.

Kussakin, G.O. - 1973. Peculiarities of the geographical and vertical distribution of marine isopods and the problem of deep sea fauna origin. Mar. Biol., 23: 19-34.

Kussakin, O.G. and G.S. Vasina. - 1993. Description of Globarcturus angelikae gen. et sp. n., the first Antarctic hadal arcturid from the South Sandwich Trench (Crustacea, Isopoda: Arcturidae). Zool. Inst. St. Petersb., 2: 241-245.

Kussakin, O.G. and A.V. Rybakov. - 1995. Protognathia waegelei, sp. n. (Crustacea, Isopoda, Flabellifera) - a new species of rare and poorly known family Protognathiidae from the Antarctic. Biol. Morja, 21(1): 21-28.

Lawver, L.A., L.M. Gahagan and M.F. Coffin. - 1992. The development of paleoseaways around Antarctica. In: J. P. Kennett and D. A. Warnke (eds.), The Antarctic paleoenvironment: A perspective on global change. Part One, pp. 7-30. Ant. Res. Ser., 56.

Ledoyer, M. - 1990a. Mysidacea (Crustacea) de la campagne "EPOS 3" en mer de Weddell, Antarctique. Mesogée, 50: 37 44.

Ledoyer, M. - 1990b. Mysidacés et Caridés benthiques (Crustacea) de la campagne MD/JASUS aux iles Saint Paul et Amsterdam (Océan Indien). Mesogée, 50: 45-51.

Lipps, J.M., T.E. Ronan and T.E. DeLaca. - 1979. Life below the Ross Ice shelf. Science, 203: 447-449.

Lomakina, N.B. - 1968. Cumacea of the Antarctic region. Issled Faunei Morei, 6: 97-140.

Luxmore, R.A. - 1984. A comparison of the respiration rate of some Antarctic isopods with species from lower latitudes. Brit. Antarct. Surv. Bull., 62: 53-66.

Malyutina, M.V. - 1997. Disconectes vanhoeffeni sp. n., a new species of isopod of the family Munnopsidae from the South Sandwich Trench of the Antarctic. Russ. J. Mar. Biol., 23 (3): 152-156.

Menzies, R.J., R.Y. George and G.T. Rowe. - 1973. Abyssal environment and ecology of the world oceans. Wiley, New York.

Moyano, H.L. - 1996. Holocene bryozoan links between Australia, New Zealand, southern South America, and Antarctica - a preliminary evaluation. In: D. P. Gordon, A. M. Smith and J. A. Grant-Mackie (eds.): Bryozoans in space and time, pp. 207219. National Institute of Water and Atmospheric Research Ltd., Wellington, New Zealand.

Mühlenhardt-Siegel, U. - 1999. The biogeography of Cumacea. A 
comparison between South America, the Subantarctic islands, and Antarctica: Present state of the art. Sci. Mar., 63(Supl. 1): 295-302.

Park, J.-Y. and J.W. Wägele. - 1995. On a small collection of Valvifera (Crustacea, Isopoda) from the Magellan Strait, with description of Platidotea magellanica n. gen. n. sp. Bull. Zool. Mus., 14 (6): 57-99

Patarnello, T.L., L. Bargelloni, V. Varotto and B. Battaglia. - 1996. Krill evolution and the Antarctic ocean currents: evidence of vicariant speciation as inferred by molecular data. Mar. Biol., 126: 603-608.

Picken, G.B. - 1980. Reproductive adaptations of Antarctic benthic invertebrates. In: W. N. Bonner and R. J. Berry (eds.), Ecology in the Antarctic, pp. 67-75. Academic Press, London.

Piepenburg, D. - 1988. Zur Zusammensetzung der Bodenfauna der westlichen Fram-Straße. Ber. Polarforsch., 52: 1-118.

Piepenburg, D., J. Voß and J. Gutt. - 1997. Assemblages of sea stars (Echinodermata: Asteroidea) and brittle stars (Echinodermata: Ophiuroidea) in the Weddell Sea (Antarctica) and off northeast Greenland (Arctic): a comparison of diversity and abundance. Polar Biol., 17: 305-322.

Pirez, A.M. and P.Y.G. Sumida. - 1997. The valviferan isopods (Crustacea Peracarida) from Bransfield Strait and adjacent waters, Antarctica. Ophelia, 46 (1): 11-34.

Poore, G.C.B., J. Just and B.F. Cohen. - 1994. Composition and diversity of Crustacea Isopoda of the southeastern Australian continental slope. Deep-Sea Res., 41: 667-693.

Schmidt, A. - 1999. Die Tanaidaceenfauna des Beagle-Kanals und ihre Beziehungen zur Fauna des antarktischen Festlandsockels. Diploma thesis Univ. Hamburg. 114 pp.

Schnitker, D. - 1980. Global paleoceanography and its deep water linkage to the Antarctic glaciation. Earth-Sci. Rev., 16: 1-20.

Shackleton. N.J. and J.P. Kennett. - 1975. Palaeotemperature history of the Cenozoic and the initiation of the Antarctic glaciation: oxygene and carbon isotope analyses in DSDP sites 277, 279 and 281. Init. Repts. Deep Sea Drill. Proj., 29: 743-756.

Shackleton, N.J. and A. Boersma. - 1981. The climate of the Eocene Ocean. J. Geol. Soc., Lond., 138: 153-157.

Sieg, J. - 1983. Evolution of Tanaidacea. In: F. R. Schram (ed.), Crustacean phylogeny, pp. 363-379. Balkema, Rotterdam.

Sieg, J. - 1984. Neue Erkenntnisse zum System der Tanaidacea. Eine phylogenetische Studie. Zoologica, 136: 1-132.

Sieg, J. - 1986. Distribution of the Tanaidacea: Synopsis of the known data and suggestions on possible distribution patterns. In: R. H. Gore and K. L. Heck (eds.), Crustacean Biogeography, pp. 165-194. Balkema, Rotterdam, Boston.

Sieg, J. - 1988. Das phylogenetische System der Tanaidacea und die Frage nach dem Alter und der Herkunft der Crustaceenfauna des antarktischen Festlandsockels. Z. zool. Syst. Evolutforsch., 26: 363-379.

Storey, B.C. - 1996. Microplates and mantle plumes in Antarctica. Terra Ant., 3 (2): 91-102.

Teodorczyk, W. and J.W. Wägele. - 1994. On Antarctic species of the genus Munna Krøyer, 1839 (Crustacea, Isopoda, Asellota, Munnidae). Bull. Mus. nat. Hist., Paris, 16: 111-201.

Voß, J. - 1988. Zoogeographie und Gemeinschaftsanalyse des Makrozoobenthos des Weddellmeeres (Antarktis). Ber. Polarforsch., 45: 1-145.

Wägele, J.W. - 1987. On the reproductive biology of Ceratoserolis trilobitoides (Crustacea, Isopoda): Latitudinal variation of fecundity and embryonic development. Polar Biol., 7: 11-24.
Wägele, J.W. - 1988. Aspects of the life cyle of the Antarctic fish parasite Gnathia calva Vanhöffen (Crustacea: Isopoda). Polar Biol., 8: 287-291.

Wägele, J.W. - 1989. Evolution und phylogenetisches System der Isopoda. Stand der Forschung und neue Erkenntnisse. Zoologica, 1-262.

Wägele, J.W. - 1990. Growth in captivity and aspects of reproductive biology of the Antarctic fish parasite Aega antarctica (Crustacea, Isopoda). Polar Biol., 10: 521-527.

Wägele, J.W. - 1992. Systematische Untersuchungen an Tieren polarer Regionen. Benthosökologie im Südpolarmeer und die Lebensweise und Evolution antarktischer Isopoda (Crustacea: Peracarida). Verh. Dtsch. Zool. Ges., 85.2: 259-270.

Wägele, J.W. - 1994. Notes on Antarctic and South American Serolidae (Crustacea, Isopoda) with remarks on the phylogenetic biogeography and description of new genera. Zool. Jb. Syst., 121: 3-69.

Wägele, J.W. and A. Brandt. - 1992. Aspects of the biogeography and biology of Antarctic isopods (Crustacea): In: V. A. Gallardo, O. Ferretti and H. I. Moyano (eds.): Oceanografia en Antartide, pp. 417-420. Ediciones Documentas, Santiago.

Watling, L. and M. Thurston. - 1989. Antarctica as an evolutionary incubator: evidence from the cladistic biogeography of the amphipod family Iphimediidae. In: J. A. Crame (ed.): Origin and evolution of Antarctic biota. Geol. Soc. Spec. Publ., 47: 297-313.

White, M.G. - 1970. Aspects of the breeding biology of Glyptonotus antarcticus (Eights) (Crustacea, Isopoda) at Signy Island, South Orkney Islands. In: M. W. Holdgate (ed.): Antarctic Ecology, pp. 279-285. Academic Press, London.

White, M.G. - 1975. Oxygen consumption and nitrogen excretion by the gigant Antarctic isopod Glyptonotus antarcticus Eights in relation to cold-adapted metabolism in marine polar poikilotherms. Proc. $9^{\text {th }}$ Eur. mar. biol. Symp. 1975, pp. 707-724. University Press, Aberdeen.

White, M.G. - 1984. Marine benthos. In: R. M. Laws (ed.): Antarctic Ecology, pp. 421-461. Ant. Ecol., 2, Academic Press, London.

Wilson, G.D.F. - 1980. New insights into the colonisation of the deep sea: systematics and zoogeography of the Munnidae and Pleurogonidae comb. nov. (Isopoda: Janiroidea). J. Nat. Hist., 14: $215-236$.

Winkler, H. - 1992. On two Magellanic Munnidae: a new species of Munna and Uromunna nana (Nordenstam, 1933) (Crustacea: Isopoda: Asellota). J. nat. Hist., 26(2): 311-326.

Winkler, H. - 1994a. Charakterisierung der Isopodenfauna (Crustacea, Malacostraca) des Scotia Bogens aus biogeographischer Sicht: Ein multivariater Ansatz. Ber. Polarforsch., 139: 1-196.

Winkler, H. - 1994b. Paramunnidae (Crustacea: Isopoda: Asellota) from the Magellan Strait. Zool. J. Linn. Soc., 110: 243-296.

Wittmann, K.J. - 1991. Systematisch-faunistische und biomineralogische Untersuchungen an Mysidacea (Crustacea) des Weddellmeeres. Ber. Polarforsch., 86: 37-40.

Zinsmeister, W.J. - 1982a. Late Cretaceous - Early Tertiary molluscan biogeography of the southern circum-Pacific. J. Paleontol., 56 (1): 84-102.

Zinsmeister, W.J. - 1982b. Review of the Upper Cretaceous Lower Tertiary Sequence on Seymore Island, Antarctica. J. Geol. Soc. London, 139: 779-785.

Zinsmeister, W.J. and R.M. Feldmann. - 1984. Cenozoic high latitude heterochroneity of southern hemisphere marine faunas. Science, 224: 281-283. 